\title{
Effect of China berry crude extracts on broad mites in vivo and in vitro
}

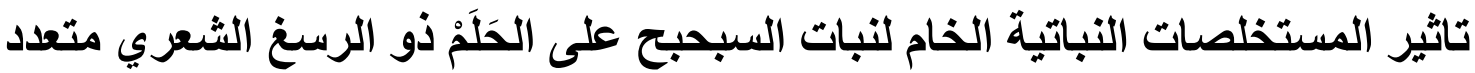

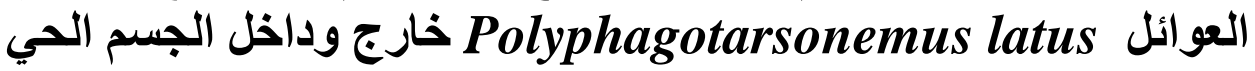

Biotechnology Dept., College of science, Al Nahrain university

*Plant protection Dept., College of Agriculture, Baghdad University

\begin{abstract}
Tissue cultures were established for leaf and stem of china berry (Melia azedarach) tree. Using MS media the best regulator to form callus were $6 \mathrm{mg} / \mathrm{l}$ BAP, all other concentrations did not give callus. The crude extracts from leaves and callus established from leaves were extracted with water and ethanol with different concentrations. In ethanol extracts the least concentration 0.0001 half of the treated parasites were killed in 24 hours while the number increases as the concentration increase. However, in callus the ethanol extracts were much higher about 8.5 were killed in the above concentration. In water extracts the least concentration 0.0001 killed half of the treated parasites in 24 hours. This number was increased 8 or 9 in 48 and 72 hours respectively. These results give us preliminary idea about the biological control of this dangerous parasite.
\end{abstract}

المستخلص

اخذت اجزاء خضرية (ورقة ، ساق) لنبات السبحبح M. azedarach وزعت على وسط غذائي MS مجهز بتوليفات مختلفة من السايتوكاينين BAP واختير احسن تركيز mg/L 6 لتكوين الكالس ـ تم استخلاص المركبات الفعالة من هذا الكالس واوراق الثجرة المزروعة بالحقل باستعمال الماء والكحول بتراكيز مختلفة ـ في المستخلص الكحولي كاتت الجرعة النصف قاتلة 0.0001 في مدة 24 ساعة ، وازداد تاثير هذا المستخلص كلما زاد التركيز والوقت الى 48 و 72 ساعة . . اما مستخلص الكالس الكحولي لنفس التركيز فقد ازداد عدد الافراد المقتولة الى 8.5 فرد في 24 ساعة ـ تزداد نسبة القتل كلما زاد التركيز والمدة ـ اما في المستخلص المائي كاتت 
الجرعة النصف قاتلة هي 0.0001 في مدة 24 ساعة . في حين كان عدد الافراد المقتولة 8 و 9 عند زيادة المدة

الى 48 و 72 ساعة على التوالي ـ ان هذا البحث يعطينا فكرة اولية عن المكافحة الحيوية لهذا الطقيلي الخطير ـ.

\section{Introduction}

China berry (Melia azedarach) is fast growing tree belongs to Mahogany family. China berry is native in Asia and America. It has been introduced as an ornamental shade tree because of its large compound leaves. It's fruits are round yellow growing in clusters. The seeds are spread by fruit eating birds [1] The tree had been used in medicinal treatments. Its bark leaves, and seeds are poisons to animal's farm [1]. Previous research showed that china berry have insecticide, antiviral, and possible anticancer properties [1]. The Broad Mites was first isolated from the terminal buds of mango [2].

Broad Mite which had been discovered in Iraq in 1997. Polyphagotarsonemus latus caused severe damage to many economic crops. Broad mite damage young leaves and fruits and sometimes causes defoliation young shoots. The most important damage is to the fruit injury of feeding sites causes premature fruit drop may occur [3]. This mites destruct plant feeder causing terminal leaves and flower buds to become malformed [4]. P. latus is a serious pest for tea, chilli, and aubergiues in china[5]. Damage usually confined to undersides of leaves, where areas between veins are brownish and dried out and brittle in severe cases. Young leaves are cupped down ward and narrower than normal [6].

The greatest infestation occurs in summer but some damage is done throughout the year. The damage tissues become brittle deformed and often have a shiny appearanc [3]. Damage is usually confined to undersides of leaves where areas between veins are brownish and dried out and brittle in severe cases. Young leaves are cropped down words and narrower than normal [7].

This mite has attacks more than sixty different plant families [8]. P. latus is serious pest of tea, chili, pepper and aborigines in china. It was reported to destroy $50 \%$ of the bean crop in new Guinea and of the lemon crop in parts of South Africa. It has reported to damage $50 \%$ of potato fields[9]. 
The importance of these Mites gave us an interest to find a natural extract to control or illuminate these infections.

The work in this paper divided in two parts:

\section{Material and Methods}

Extraction material from china berry leaves:

China berry leaves were collected from 20-30 year old tree. Leaves were dried in a shade in about $40^{\circ} \mathrm{C}$ for two weeks.

50 Grams from dried leaves were rinsed in $500 \mathrm{ml}$ distilled water to obtain water extract. Other 50 Grams from dry leaves was mixed in $500 \mathrm{ml}$ ethanol to obtain ethanol extract.

The latest mixtures (Alcohol extract) were put on orbital shaker at $35^{\circ} \mathrm{C}$ for two days. The mixture were filtrate by what man filter paper no1.The filtrate were dried in an oven at $40^{\circ} \mathrm{C}$ to obtain viscous liquid that can be dried by using incubator in $37^{\circ} \mathrm{C}$ for 3-4 days. The product stored in a refrigerator until use.

\section{Tissue culture technique:}

Leaf explants were collected from mature tree. These explants were surface sterilized in 2\% Clorox for 4 minutes, rinsed three times in sterilize distilled
1. Using crude water and Ethanol extracts from China berry leaves.

2. Establish leaf callus in MS medium with different hormones. The water and Ethanol extracts from these calli were used to control Mites.

water. Two explants were cultured in each Petri dish contains MS medium prepared earlier.

Each experiment was repeated three times, and each treatment was consisting of 20 replicates.

Media preparation:

MS 1962 was prepared as in [10]. The media was supplemented with $30 \mathrm{~g} / \mathrm{l}$ sucrose, 6mg/l BAP\& 7.5g/l Agar before autoclaving $\cdot \mathrm{pH}$ was adjusted to $5.8 \pm 1$ with $1 \mathrm{~N} \mathrm{HCL}$ or $1 \mathrm{~N} \mathrm{KOH}$. All cultures were kept in an incubator at 1000LUXand $27^{\circ} \mathrm{C}$.

Parasite treatments:

By using loop transfer a number of parasites living on Vigna sinesis leaf to wet cotton plaque in Petri dish. Vaseline was used at the leaf ends to prevent parasite moving from the leaf. $10 \mathrm{ml}$ of crude extracts were used against the parasites. The living parasites were counted after 24, 48, and 72 hours. 


\section{Results and discussion}

Tissue culture experiments :

Different concentrations of growth regulators had been used to perform callus from leaf and stem explants. In all explants no callus were formed except very weak growth of some explants this may be explained as poor response for leaf tissues. The reasons behind this are that leaf tissues may be mature and not easy dedifferentiate to produce callus which are meristematic cells in culture. Moreover, in $6 \mathrm{mg} / \mathrm{l} \mathrm{BAP}$ a good callus were formed. That means this concentration was suitable to produce callus picture (1) .

Extraction experiments:

Ethanol extracts:

In concentration 0.0001 half of treated parasites were killed in 24 hours, while the number was increased to $(8,9)$ in 48 and 72 hours respectively. However, the killed number in all other higher concentration were increased proposhinal Fig (1).
In Fig (2) ethanol for leaf callus were much higher such as in 0.0001 concentration the killed number was about 8.5 in the other concentrations they were higher.

Water extracts:

Water extract for leaf tissue and callus initiated from leaf had been preformed. As in Fig $(3,4)$ the least concentration (0.0001) killed half of the parasites used (5/10) after 24 hours of the treatments, while in 48 hours of the treatments the killed parasites were increased to 8/10 . In 72 hours of the treatments the killed number was 9/10.

Moreover, in next concentration (0.001) the killed number were higher $(6,8,9)$ in $(24,48,72)$ hours respectively.

In higher concentrations the killed parasites were higher especially after 48 hours or 72 hours of treatments.

These results give us preliminary idea about the biological control of this dangerous parasite. 


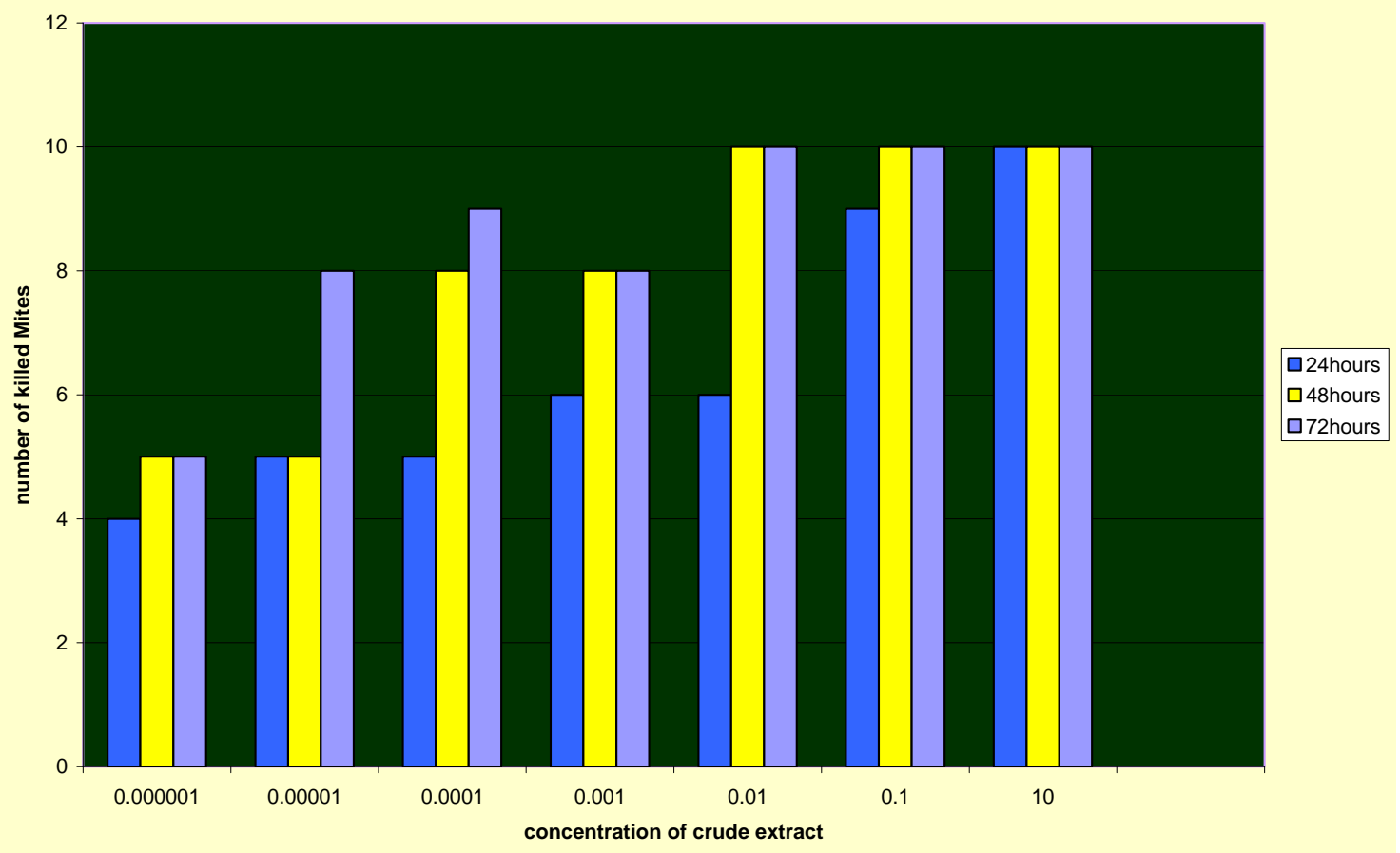

Fig (1) effect of Ethanol extract on Mites $\mathbf{n}=\mathbf{5 0}$

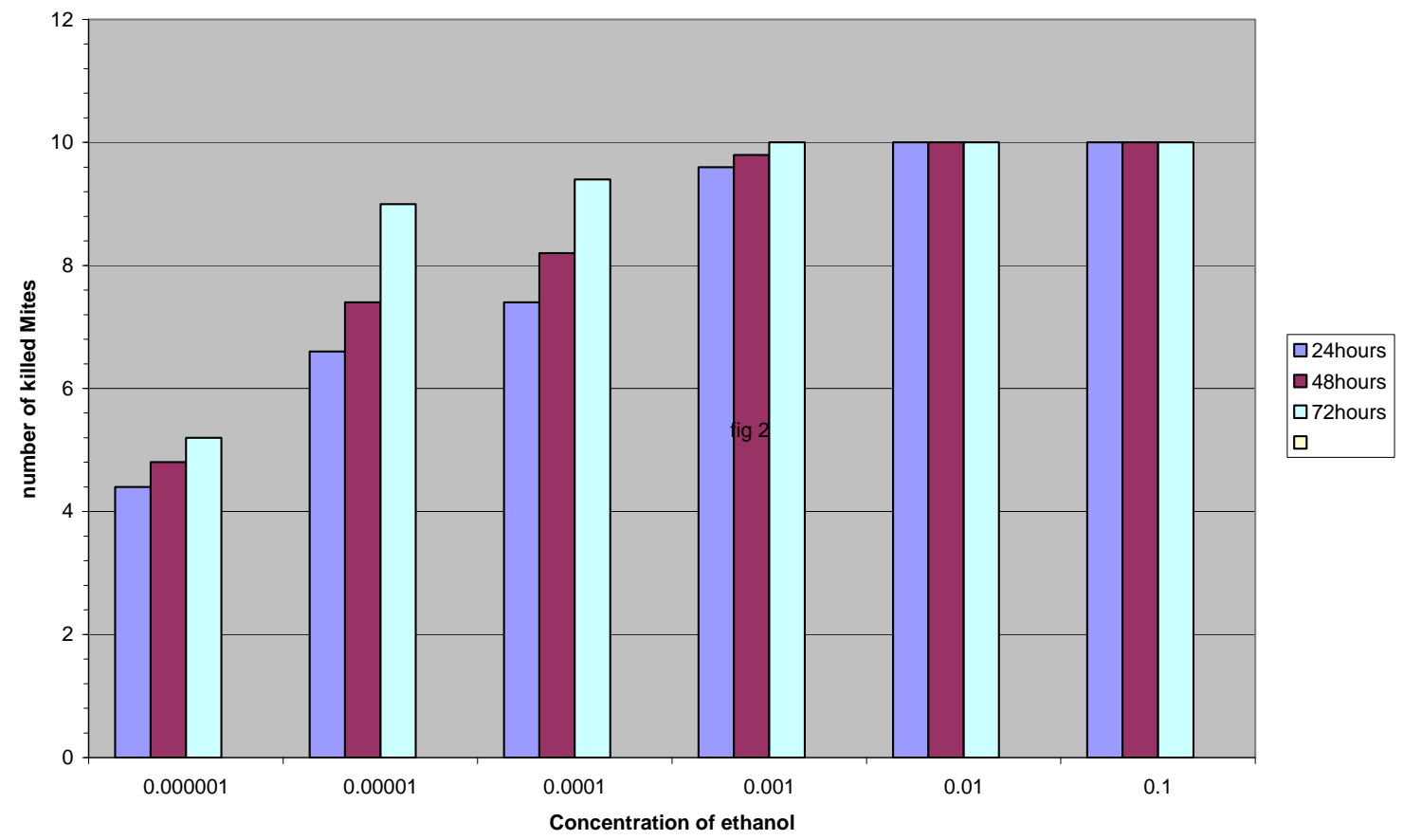

Fig (2) effect of leaf callus extracted with ethanol on Mites $\mathbf{n}=\mathbf{5 0}$ 


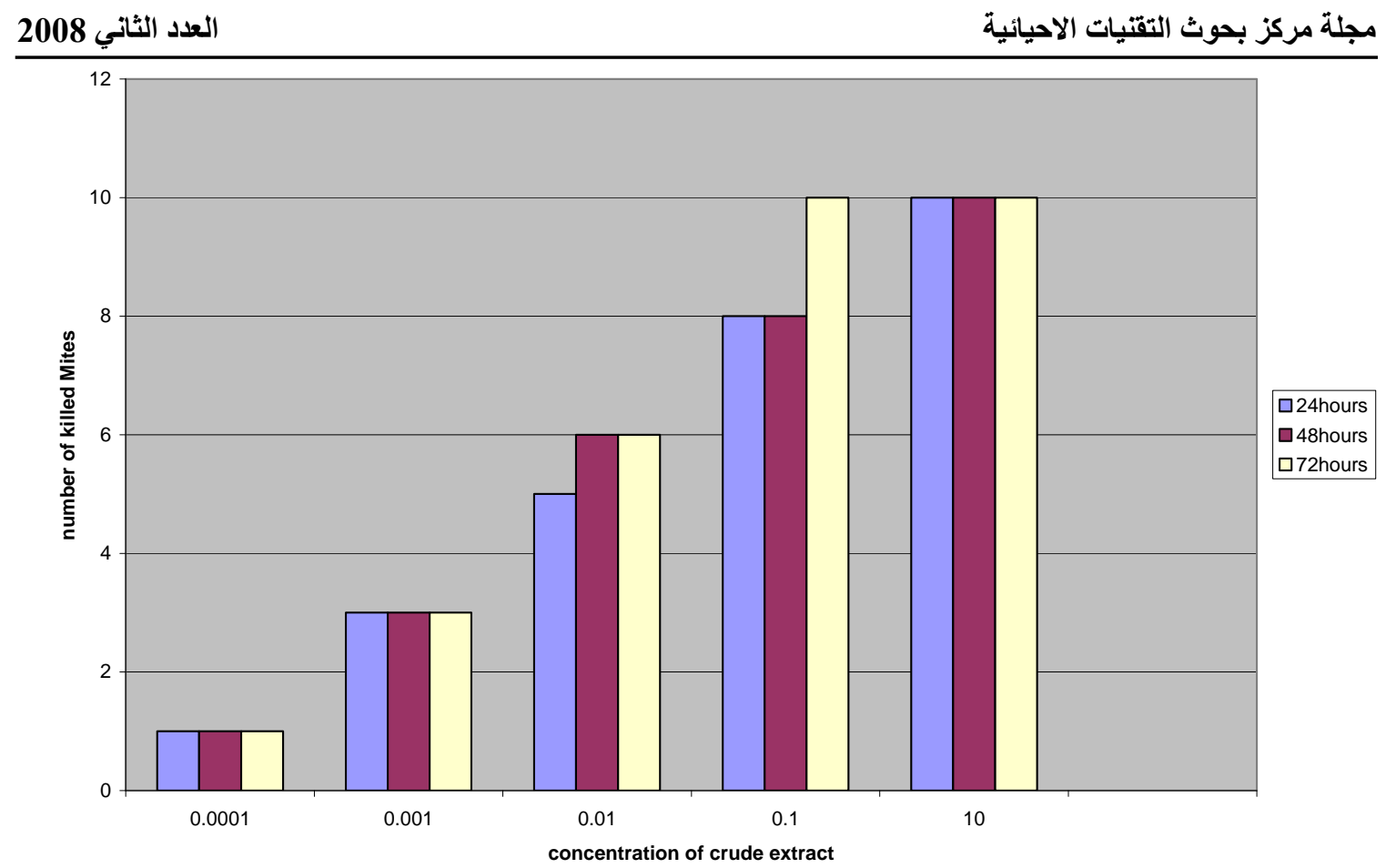

Fig (3) effect of water extracted on Mites $n=10$

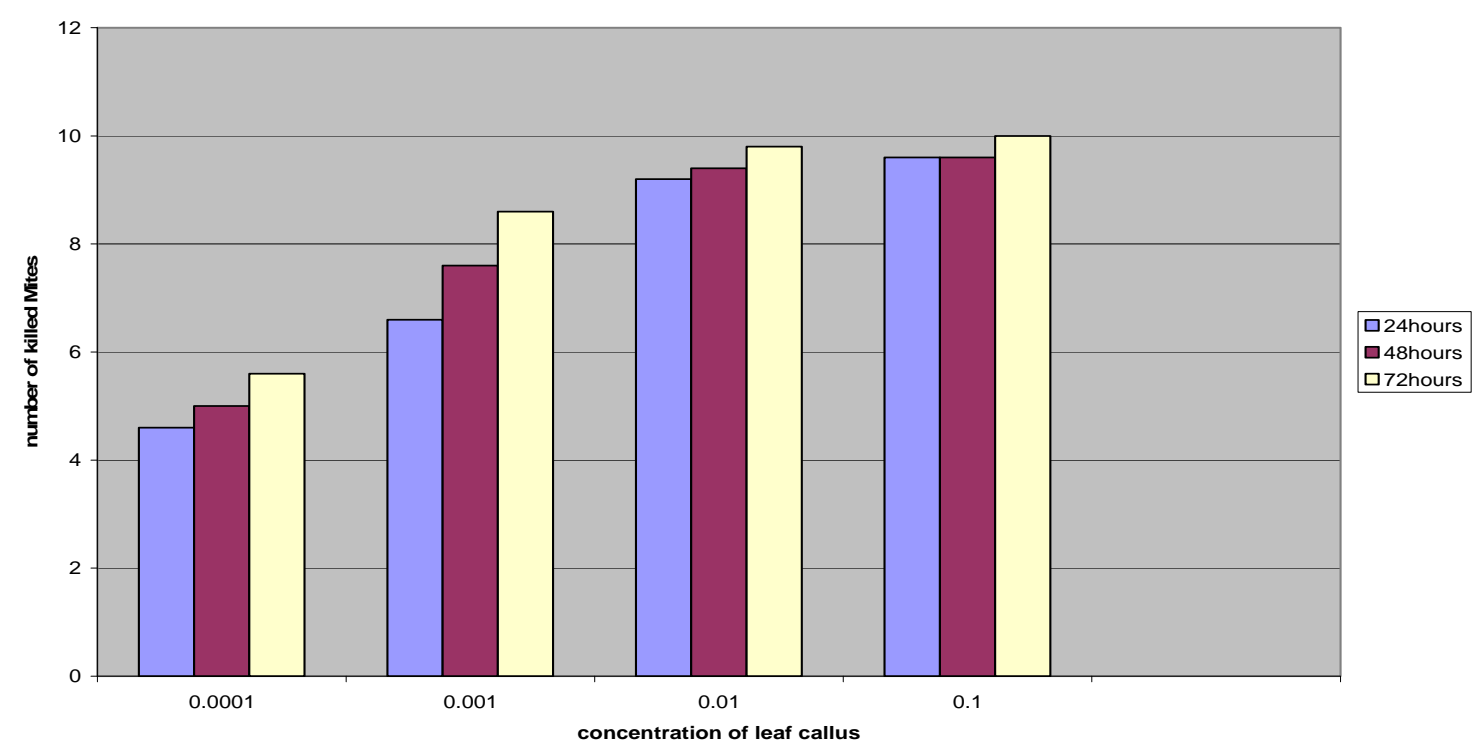

Fig (4) effect of leaf callus extracted with water on Mites $n=10$

\section{References}

1. http://www.google.com/search

2. Denmark, H. A., 2000. P. latus (bank) (acarina : tarsonemidae )
3. Pena, J. E. \& C. W., Campbell. 1994. Broud mite http://edis. Ifas.ufl. edu/ pdffiles / CH/ CH02000. 
4. Shoshana, yahom., 1999. Abstract presented in the $17^{\text {th }}$ conference of the entomological society.

5. lils, liyr, bugs, 1985. The effect of temperature \& humidity on the growth \&development of the broad mites. Acta entomologica sinica, 28(2); 181-187.

6. Bl. Parker, N. S. Talekar \& M. Skinner ., 1995. Insect pests of selected vegetables in tropical \& subtropical Asia. publication 94-427

7. Parker, B.L.; N.S. Talekar and M. Skinner, 1995. Insect pests of selected vegetables in tropical and subtropical.
8. Gerson, U. 1992. Biology and control of broad mite, Polyphagotarsonemus latus (Banks) (Acari: Tarsonemidae). Exp.Appl. Acrol. 13:163-178.

9. Al-Jboory, I. J. 2000 Biology of fertizlied and unfertilized broad mite females. Polyphagotarsonemus latus (Banks) (Tarsonemidae: Acari) under different Temperatures. Iraqi J. Agric. Vol.5 No.7 pp.100-105. Dec./2000

10. Murashiqe, T. and skoog, F., (1962): A revised medium for rapid growth and bioassays with tobacco tissue cultures. Physiol. plant.15:473-497. 